\title{
Improvements in the Finnish agri-environment scheme are needed in order to support rich farmland avifauna
}

\author{
Ville Vepsäläinen ${ }^{1, *}$, Juha Tiainen², Jyrki Holopainen², Markus Piha1 \& \\ Tuomas Seimola ${ }^{2}$
}

1) Finnish Museum of Natural History, P.O. Box 17, Fl-00014 University of Helsinki, Finland
(*corresponding author's e-mail: ville.vepsalainen@helsinki.fi)
2) Finnish Game and Fisheries Research Institute, P.O. Box 2, Fl-00731 Helsinki, Finland

Received 18 Sep. 2009, revised version received 2 Feb. 2010, accepted 2 Feb. 2010

Vepsäläinen, V., Tiainen, J., Holopainen, J., Piha, M. \& Seimola, T. 2010: Improvements in the Finnish agri-environment scheme are needed in order to support rich farmland avifauna. - Ann. Zool. Fennici 47: 287-305.

National agri-environment schemes (AESs) aim to promote sustainable farming and protect farmland biodiversity. For efficient maintenance of biodiversity, it is essential to understand the habitat requirements of fauna, and its responses to farming practices. This study examined the importance of different habitat characteristics and habitat heterogeneity for farmland birds in boreal agricultural landscapes, focusing on species in open arable habitats (true field species) and bushy field-edge habitats. Density, species richness, and species composition were studied in a multivariate space, and along environmental gradients. The relevance of the biodiversity-related measures of the Finnish AES regarding the habitat needs of farmland birds was examined. Non-cropped habitat heterogeneity (especially open ditches and habitat patch richness) increased the density and species richness. Crop diversity increased the species richness of true field species. Ordinations revealed a gradient from large open arable to small field areas, and a relation to habitat heterogeneity. The AES places insufficient emphasis on biodiversity issues.

\section{Introduction}

On a global scale, the intensification of agriculture is one of the main causes of a widespread loss of biodiversity and habitat heterogeneity (Stoate et al. 2001, Tilman et al. 2001, Benton et al. 2003, Green et al. 2005). It is generally accepted as the main driver of population decline among many farmland bird species across Europe (see e.g. Hanski \& Tiainen 1988, Fuller et al. 1995, Siriwardena et al. 1998, Chamberlain et al. 2000, Tiainen \& Pakkala
2001, Donald et al. 2001, Robinson \& Sutherland, 2002, Kujawa 2002, Newton 2004, Laiolo 2005, Wretenberg et al. 2006). The loss of habitat heterogeneity (along with other consequences of agricultural intensification and increases in agricultural production) has been most severe in the countries of the European Union (EU), in which the Common Agricultural Policy (CAP) sets a broad framework for agricultural practices and objectives (Donald et al. 2001, Donald et al. 2002, Benton et al. 2003).

Studies on the effects of agriculture on biodi- 
versity offer tools to influence agricultural policy in Europe, since they provide information for agri-environment schemes (AESs). AESs are a form of environmental regulation included in the CAP, in which a proportion of the subsidies paid to farmers is directed towards agricultural practices and actions that are thought to benefit the environment. At present, less than $5 \%$ of the CAP budget is targeted at AESs (Donald et al. 2006). Studies on the effects of AESs on the environment and on biodiversity have so far failed to prove clear positive effects deriving from the schemes. It appears that the studies in question have resulted in unclear and mutually contradictory results, possibly due to differences in temporal and spatial scales and in the taxa investigated (Kleijn et al. 2001, Kleijn \& Sutherland 2003).

Since Finland joined the EU in 1995, it has implemented an AES (with coverage of approximately $94 \%$ of farms and over $95 \%$ of farmland, see Kuussaari et al. 2004a) as part of the 'Horizontal Rural Development Programme'. The Finnish AES is predominantly aimed at water protection with a view to preventing nutrientleaching and erosion from fields. The Finnish AES is composed of measures at three levels. The basic measures and also one of the additional measures are obligatory, whereas the agreements for special measures are voluntary. There are more measures targeted at biodiversity preservation in the special agreement part of the AES than in the basic measures. A mid-term evaluation of the second subsidy period of the Finnish AES concluded that the scheme had in practice contributed to some aspects of biodiversity maintenance, but that the current measures were probably insufficient to stop the prolonged decline in farmland biodiversity (Kuussaari et al. 2004a). With regard to birds, the preliminary results suggested that the establishment of border strips and zones, set-asides, and organic farming had shown positive effects, but that overall, the declining trend of farmland birds had not been reversed to any significant extent during the AES (Tiainen et al. 2004).

In boreal conditions, the trends displayed by many bird species are different from those seen in central or western Europe as regards direction, timing and magnitude (Rintala et al.
2003, BirdLife International 2004, Vepsäläinen et al. 2005a, 2007, Piha et al. 2007a, Rintala $\&$ Tiainen 2007). This may be due to differences not only in climate and geographical location, but also in the extent and structure of agricultural landscapes. In Europe, about one half of the land area is covered by agricultural and grassland habitats (Tucker \& Dixon 1997). In Finland, such land is mostly located in the boreal vegetation zone in the southern part of the country. While forests are the dominating habitat type, covering about $75 \%$ of the total land area (Anon. 2005), the area under cultivation (including fallow) is roughly $7 \%$ (though about $30 \%$ in the south of the country), with springsown cereal cultivation dominating and covering approximately one half of the arable land (Anon. 2006). Thus, in Finland (and in many other parts of Fennoscandia) the agricultural areas are generally surrounded by forests, whereas the opposite is the case in most other European countries, where farmland dominates the landscapes (Tucker \& Dixon 1997). Despite the small proportion of the total land area covered by arable land, Finnish farmland avifauna is species-rich and dense (Tiainen \& Pakkala 2001, BirdLife International 2004). The Finnish populations of some species, for example the curlew (Numenius arquata; 35 000-50 000 pairs), the lapwing (Vanellus vanellus; 50 000-80 000 pairs), and the scarlet rosefinch (Carpodacus erythrinus; 250 000-350 000 pairs), constitute a substantial proportion of their overall European populations (BirdLife International 2004).

The importance of habitat heterogeneity including both cultivated areas and non-cropped 'marginal' habitats - for farmland bird diversity has been supported by numerous studies from different parts of Europe (Böhning-Gaese 1997, Pärt \& Söderström 1999, Tryjanowski 1999 and the review therein, review by Newton 2004, Heikkinen et al. 2004, Fuller et al. 2004, Laiolo 2005, Bracken \& Bolger 2006, Herzon \& O'Hara 2007), hence it is obvious that in AESs this issue should be emphasised. In addition to locally targeted conservation schemes on rare species, more general conservation guidelines that would be applicable to many species are needed in AESs, at the national level, and also at the regional level (e.g. Whittingham et al. 2007). 
Thus, in studies that search for associations between farmland birds and habitat heterogeneity, one reasonable approach is to focus on species assemblages rather than on individual species. The benefits of research at the multi-species level include an increased ability to detect shared patterns of environmental response across species, and better tools to condense complex data into a form that researchers and decision-makers can readily interpret and digest (Ferrier \& Guisan 2006).

In the present study, we studied the importance of various habitat characteristics for breeding farmland bird assemblages in southern Finland, on a scale of $0.25 \mathrm{~km}^{2}$ grid cells. We examined the significance of different cultivation types, other habitat factors and habitat heterogeneity for farmland birds in cereal cultivationdominated arable landscapes. We concentrated on species belonging to two ecological groups that could be expected to be especially susceptible to the direct effects of farmland practices and agricultural intensification, namely species that breed in (1) open arable and (2) bushy field-edge habitats. The density and species richness of the two groups, and of all the different species combined, was studied via multiple linear regressions. Autocorrelation (Legendre 1993) was taken into account in the regressions by applying autoregressive modelling (Anselin 2002). Using both indirect and direct ordination methods, we studied the species composition among the assemblages in multivariate space and along environmental gradients. By using redundancy analysis (RDA) as the direct ordination method we examined also the direct responses of the species to environmental factors. To assess the relative importance of environmental and spatial variables, and their intersection, we applied variation partitioning (Borcard et al. 1992) by partial ordinations.

On the basis of the results, we discuss the relevance of the various measures included in the Finnish AES in relation to the environmental needs and habitats of the species studied. Furthermore, we put forward proposals for improvements in the measures included in future AESs, especially regarding the issue of habitat heterogeneity.

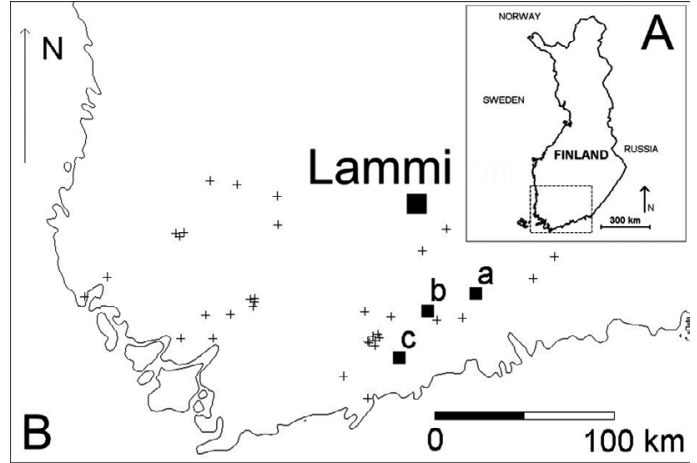

Fig. 1. - A: The location and border (jagged line) of the study area in southern Finland. - B: The locations of the 37 sub-areas (squares and crosses) in the study area. The large square indicates the location of the long-term study area of Lammi $\left(61^{\circ} 05^{\prime} \mathrm{N}, 25^{\circ} 00^{\prime} \mathrm{E}\right)$, consisting of four sub-areas (totalling $16.5 \mathrm{~km}^{2}$ ). The smaller squares and the letters $(\mathrm{a}-\mathrm{c})$ indicate the locations of three other large study areas: $a=$ Pukkila (30 $\left.\mathrm{km}^{2}\right), \mathrm{b}=$ Ohkola $\left(6.25 \mathrm{~km}^{2}\right), \mathrm{c}=$ Seutula $\left(7.5 \mathrm{~km}^{2}\right)$. The locations of the 33 smaller sub-areas (between 0.5 and $1 \mathrm{~km}^{2}$ in size) are indicated by small crosses.

\section{Material and methods}

\section{Study areas}

The study areas were located in southern Finland (Fig. 1a). The total area under study was $92 \mathrm{~km}^{2}$, and it consisted of sub-areas of different sizes and shapes: thus there were 33 squares of $1 \mathrm{~km}^{2}$, and four larger study areas, ranging from 6.25 to $30 \mathrm{~km}^{2}$ (Fig. 1b). One of the larger study areas, Lammi (Fig. 1b), consisted of four separate subareas, and totalled $16.5 \mathrm{~km}^{2}$ in size. All the areas consisted of cultivated farmland, surrounded mainly by forests, scattered settlement and mires. A grid of $500 \times 500 \mathrm{~m}$ cell size was laid on these areas via a GIS (MapInfo Professional 8.0, MapInfo Co.), and the resulting 368 cells were used as individual samples in the study. The scale of the 25-ha grid cells was chosen for this study for two reasons: first of all, the scale was comparable to the average arable area of Finnish farms (28 ha in 2000, Anon. 2001), and secondly, previous studies in Finland using this scale have embraced many aspects of land-use and landscape structure variation that are important for birds (Heikkinen et al. 2004, Luoto et al. 2004). Grid cells containing less than 5 hectares 
of farmland (i.e. arable fields, including pastures and set-asides) were discarded. This reduced the size of three study areas to $0.75 \mathrm{~km}^{2}$ and one area to $0.5 \mathrm{~km}^{2}$.

\section{Bird data}

\section{Mapping the territories}

The mapping of breeding farmland birds was conducted in 2001. For this study, we included 20 species found in open arable habitats and field edge/bush habitats (Appendix 1). We classified the species as either species belonging to open arable habitats (i.e. 'true' field species), or else as species of edge and bush habitats, according to their predominant habitat use in agricultural environments (Appendix 1). We generally followed the classification by Tiainen and Pakkala (2001) but included only two of their ecological groups. The data included seven species with an unfavourable conservation status in Europe (i.e. SPEC species) (Appendix 1).

We used a two-visit application of the standard territory-mapping method (see Bibby et al. 2000). This method has been shown to provide reasonable estimates of farmland bird territory numbers in Finnish agroecosystems (Tiainen et al. 1985, Tiainen \& Pakkala 2000, Vepsäläinen et al. 2005a, Vepsäläinen et al. 2005b, Piha et al. 2007a, Piha et al. 2007b). The first visit was made during the last three weeks of May, and the second visit during the first three weeks of June. The censuses were conducted by ten professional field ornithologists. During a census morning (duration about $6-8$ hours after sunrise) a field worker thoroughly censused an average of 100 ha of arable land. The total number of fieldwork days was approximately 160 . Special attention was paid to recording simultaneous observations of territorial behaviour within species (e.g. singing males, alerting pairs), as these are essential for the identification of the correct number of territories. Special attention was also paid to mapping nest locations and to counting accurate territory numbers in territory concentrations. During each field visit, several observations of the same individuals were gathered; hence territory interpretations and the definitions of territory centres were based on more than merely single observations from the two visits. The interpretations were arrived at according to a standard practice developed for studies on agricultural birds in Finland (Tiainen \& Pakkala 2000, 2001). Having located the territory centres on a map, we digitised them onto a GIS database (MapInfo).

\section{Habitat data}

Habitat data (Table 1) were mainly obtained from the Information Centre of the Finnish Ministry of Agriculture and Forestry, and from digital CORINE Land Cover 2000 satellite images (Härmä et al. 2004). Data were also collected in the field by identifying land-use types and by mapping land-use boundaries. Habitats were classified as belonging to several types (Table 1). The classification of arable land-use types was based on differences in the intensity of agricultural practices (spring cereals and broad-leaved crops being the most intensively managed) and on the presence/absence of springtime vegetation cover (spring cereal and root crop fields being bare at the beginning of the breeding season). These are all factors that are known to affect the occurrence and density of Finnish farmland birds (Tiainen \& Pakkala 2001, Piha et al. 2003, Vepsäläinen et al. 2005b). Winter cereals were included in the managed grassland category, because their total amount was very small and they occurred only in a few study areas, and because they provide similar shelter to birds in spring. In addition to area variables, linear and point-like habitat features were also recorded (small-scale habitat elements, roads and ditches, Table 1).

The values of the variables for individual grid cells were calculated in the GIS by MapInfo Professional 8.0 and FRAGSTATS (McGarigal et al. 2002) software. The 'Field context' variable refers to the total area of agricultural land in the eight grid cells adjoining an individual grid cell; this variable was calculated from the CORINE satellite image data (pixel size $25 \times$ $25 \mathrm{~m}$ ). The 'Openness' of a grid cell was measured as the distance from the grid centre to the nearest forest (patches $\leq 2$ ha not included). In 
addition, 'Patch richness' was calculated as the number of habitat types in a grid cell.

\section{Statistical analyses}

\section{Ordinations}

We carried out the ordination analyses using the Vegan package of the $\mathrm{R}$ statistical software (Oksanen et al. 2007). We used a detrended correspondence analysis (DCA; Hill \& Gauch 1980) as an indirect ordination technique to examine variation in bird assemblages and abundance among samples. In indirect ordination, gradients in community or assemblage structure are derived from the species data independently of the environmental variables. The environmental interpretation of the DCA ordination results was achieved by fitting environmental vectors onto ordination (utilising for this the envfit function of the Vegan package). In vector fitting, an environmental variable is represented in the resulting ordination plot by an arrow that points in the direction of the most rapid change in the environmental variable, the length of the arrow being proportional to the correlation between the ordination and the variable (Oksanen 2006).

To explain the variance in the species assemblage density data, and to study the responses of individual species to explanatory environmental and spatial factors, we used a redundancy analysis (RDA). RDA is a direct (i.e. constrained) ordination method which is essentially a form of principal component analysis (PCA), and thus is based on regression methodology. In RDA, the sampling unit locations are restricted to linear combinations of environmental variables (Legendre \& Legendre 1998). RDA is a suitable method when both species and environmental data sets are linear, and when an asymmetric analysis is required (Kenkel 2006). To achieve linearity in the species data covariance matrix, the density data were transformed by Hellinger

Table 1. Descriptive statistics on the habitats for the study area $\left(92 \mathrm{~km}^{2}\right)$ : Mean refers to the mean for $500 \times 500 \mathrm{~m}$ grid cells $(n=368)$, 'Agricultural land' refers to all habitats except forests, mires, water bodies and wetlands, and 'Arable land' refers to all field types combined.

\begin{tabular}{|c|c|c|c|}
\hline Habitat & Total amount & Mean & $\begin{array}{c}\text { Prevalence } \\
\text { (number of cells) }\end{array}$ \\
\hline Agricultural land & $66.9 \mathrm{~km}^{2}$ & 18.2 ha & 368 \\
\hline Arable land & $58.4 \mathrm{~km}^{2}$ & 15.9 ha & 368 \\
\hline Spring cereals & $32.5 \mathrm{~km}^{2}$ & 8.8 ha & 360 \\
\hline $\begin{array}{l}\text { Managed grasslands, including pastures and winter } \\
\text { cereals }\end{array}$ & $15.6 \mathrm{~km}^{2}$ & 3.9 ha & 332 \\
\hline $\begin{array}{l}\text { Set-asides, meadows, non-managed grassland habitats } \\
\text { (including open verges) }\end{array}$ & $3.7 \mathrm{~km}^{2}$ & $1.0 \mathrm{ha}$ & 262 \\
\hline Broad-leaved crops* & $6.6 \mathrm{~km}^{2}$ & $1.8 \mathrm{ha}$ & 185 \\
\hline Settlement (including farm yards and gardens) & $3.9 \mathrm{~km}^{2}$ & $1.1 \mathrm{ha}$ & 274 \\
\hline $\begin{array}{l}\text { Field context (total area of agricultural landscape in } \\
\text { surrounding cells) }\end{array}$ & $405 \mathrm{~km}^{2}$ & 110 ha & \\
\hline No. of small-scale habitat elements ${ }^{\star *}$ & 1820 & 4.9 & 315 \\
\hline Roads*** & $198.7 \mathrm{~km}$ & $540 \mathrm{~m}$ & 321 \\
\hline Open ditches*** & $392.5 \mathrm{~km}$ & $1066 \mathrm{~m}$ & 298 \\
\hline 'Openness' (distance to forest edge) & - & $136 \mathrm{~m}$ & 368 \\
\hline $\begin{array}{l}\text { Forests (including forest patches }>2 \text { ha), water bodies, } \\
\text { mires and other wetlands }\end{array}$ & $25.1 \mathrm{~km}^{2}$ & 6.8 ha & 309 \\
\hline
\end{tabular}

\footnotetext{
* Mainly sugar beet, potato and turnip rape. Includes also special cultivations that are few in number, such as pea and carrot.

** Includes bush and forest patches/islets $\leq 2 \mathrm{ha}$; ditches with bushes and trees on the banks, road and field verges (not field-forest verges); wood avenues; and barns with their surroundings. Total area $2.4 \mathrm{~km}^{2}$ (included in the agricultural land).

*** Open ditches $=$ ditches without bush or tree vegetation. Total combined area of roads and open ditches $=2.2 \mathrm{~km}{ }^{2}$ (included in the agricultural land).
} 
distance transformation (Legendre \& Gallagher 2001). The transformation allows species data with numerous zeros (i.e. 'long gradients', Kenkel 2006) to be analysed by Euclidean-based ordination methods.

Densities, calculated as the number of territories per $\mathrm{km}^{2}$ of agricultural land (Table 1) in grid cells, were used as bird abundance data in the ordinations. The rarest species in the data set, the grasshopper warbler (Appendix 1), was omitted because of an insufficient number of observations. The selection of the explanatory environmental variables for RDA was conducted on an a priori basis (rather than by using any of the automatic selection tools of statistical software: see Oksanen 2006, Oksanen et al. 2007). When selecting the environmental variables, we took account of the ecology of the study species and the known general effects of agriculture on birds in Finland (see e.g. Väisänen et al. 1998, Tiainen \& Pakkala 2001, Piha et al. 2003, Vepsäläinen et al. 2005b). The variables listed in Table 1 were used as explanatory variables, excluding the area of forests, mires, water bodies and wetlands (and also the merely descriptive categories 'Agricultural land' and 'Arable land' that naturally strongly correlate with the cultivation types). The omissions were based on the species selected for the study, their general habitat use, and the objectives of this study (see above). All the variables were $\log$-transformed $[\ln (x+1)]$ for the analyses, except for the variable 'Openness' (i.e. distance to the forest edge), which gives a negative value when the grid centre is in the forest. Patch richness was used as a further explanatory variable in the analyses. For DCA vector fitting (see above) we included also the number of species $(S)$, the length of forest edge in a grid cell, the arable area, and the ShannonWiener species diversity index, to see how they correlated with the ordination.

\section{Spatial aspects}

Spatial autocorrelation is a common statistical property of ecological variables observed across geographic space. Because of autocorrelation, the values of particular variables in neighbouring sites are more or less similar to what they would be in a random set of observations (Legendre 1993).

For a direct ordination (RDA), the five terms for a quadratic trend surface analysis (i.e. centred geographical coordinates $x$ and $y$ of the grid cells, with their cross-product, and the higher terms $x y, x^{2}$ and $y^{2}$; Anselin 2006) were calculated for each of the grid cells using GeoDa (version 0.9.5-i) software (Anselin et al. 2006). In addition, the sixth spatial predictor was taken as an autocovariate, i.e. the mean value of the total density of all the species in surrounding grid cells (Heikkinen et al. 2004). The number of adjoining cells varied between one and eight, depending on the size and shape of the sub-area (Fig. 1b).

Following Borcard et al. (1992), the total variation in densities was partitioned into four independent components: pure environmental, pure spatial, mixed spatial-environmental, and unexplained fractions, in order to assess the relative importance of the environmental variables (see section 'Habitat data' above) and the spatial variables (described above); also the intersection of these variables was examined.

The significance of RDAs, as well as the significances of individual environmental and spatial constraints and of individual axes, was assessed by running permutation tests (999 permutations) via the anova.cca function of the Vegan package. Only statistically significant $(p<$ 0.05 ) variables were included in the analyses and variation partitioning, and in the representation of the results by biplotting.

\section{Analyses of species richness and density using autoregressive modelling}

We studied how variation in species richness and density (both of them log-transformed, $[\ln (x+$ 1)]) were explained by the environmental variables, taking into account the location of the samples ( $x$ and $y$ coordinates of the grid cells). This was done by applying spatial lag regression models that take into account the spatial autocorrelation. The spatial lag model is a regression technique in which the basic assumption is that the response at each location $(i)$ is a function of the explanatory variables at $i$ and the values 
of the response at neighbouring locations. The spatial lag model is a widely used spatial regression technique in econometrical studies (Anselin 2002), and recently the use of the lag model (and also various related methods) has become increasingly common in a wide range of ecological studies (e.g. Lichstein et al. 2002, Tognelli \& Kelt 2004, Gimona \& Brewer 2006, Rangel et al. 2006, Piha et al. 2007b). The spatial lag model is based on a maximum likelihood estimate of the form:

$$
y=\varrho \mathbf{W} y+\mathbf{X} \beta+\varepsilon,
$$

where $y$ is a vector of observations on the dependent variable, $\mathbf{W} y$ is a spatially lagged dependent variable for the weight matrix $\mathbf{W}, \varrho$ is the autoregression parameter, $\beta$ is the vector representing the regression coefficients associated with the predictor matrix $\mathbf{X}$, and $\varepsilon$ is a vector of random error terms. For further technical issues pertaining to the model, see Anselin and Bera (1998). Ordinary $R^{2}$ values cannot be calculated for spatial regression models, but the so-called pseudo- $R^{2}$ gives the ratio of the variance of the predicted values over the variance of the observed values for the dependent variable. Thus, it serves as a rough estimate of the explanatory power of the models.

The neighbour weight (contiguity) matrix was created by using distance weighting, the distance being 707 metres (maximum distance between centres of neighbouring cells), which ensured that each cell had at least one adjoining cell (the maximum number of neighbours being eight). The significances of model variable coefficients were calculated using an ordinary $t$-test. The residual autocorrelations of the spatial lag models were studied using Moran's I test. The analyses were performed with the GeoDa (version 0.9.5-i) software (Anselin et al. 2006).

Because 33 sub-areas were small (between 0.5 and $1 \mathrm{~km}^{2}$; see section 'Study areas') and isolated from each other, they each contained only one to three neighbouring cells for an individual cell, but no cells outside the weighting distance. In such small areas variation would be extremely limited, and the spatially lagged dependent variable would obtain (almost) similar values for individual cells. To overcome this problem, spa- tial lag regression analyses were carried out for the four large areas only (I-IV in Fig. 1b) totalling $60.25 \mathrm{~km}^{2}$, i.e. two thirds of the total area under study. We studied the density and species richness of all the species combined, and also the richness of the two ecological groups, taken separately.

\section{Results}

\section{Bird abundance}

The calculations of the total number and density for the 20 species studied gave figures of 6492 territories and 97.1 pairs per $\mathrm{km}^{2}$ of agricultural land for the entire study area (Appendix 1). The three most abundant species were the skylark, yellowhammer, and whitethroat, with 2020, 1045 , and 795 territories respectively, totalling $59.5 \%$ of all territories, and a total density of 57.7 pairs per $\mathrm{km}^{2}$ of agricultural land. The combined number of territories for the seven SPEC species (Appendix 1) was 2679 (41.3\% of the total abundance), and their overall density was 40.0 pairs per $\mathrm{km}^{2}$. Exluding the skylark, the remaining SPEC species totalled 659 territories (10.2\% of the total), and the density was 9.9 pairs per $\mathrm{km}^{2}$ of agricultural land. The combined number of territories of the true field species was 3135 , with a density of 46.9 pairs per $\mathrm{km}^{2}$. The corresponding figures for the edge/bush species were 3357 and 50.2.

\section{Ordinations of bird density data}

DCA of the bird data (Table 2) well separated the two species groups (i.e. the species occupying open arable habitats and the species occupying bush and edge habitats; see Fig. 2). The rather low eigenvalue of the first axis (which is equal to the correlation coefficient between species scores and sample scores) indicates that the species were homogeneously distributed among samples across the study area. Subsequent fitting of variables onto the ordination revealed that 11 variables correlated significantly with the ordination (Fig 2). The first axis was associated especially with the species of open arable habi- 


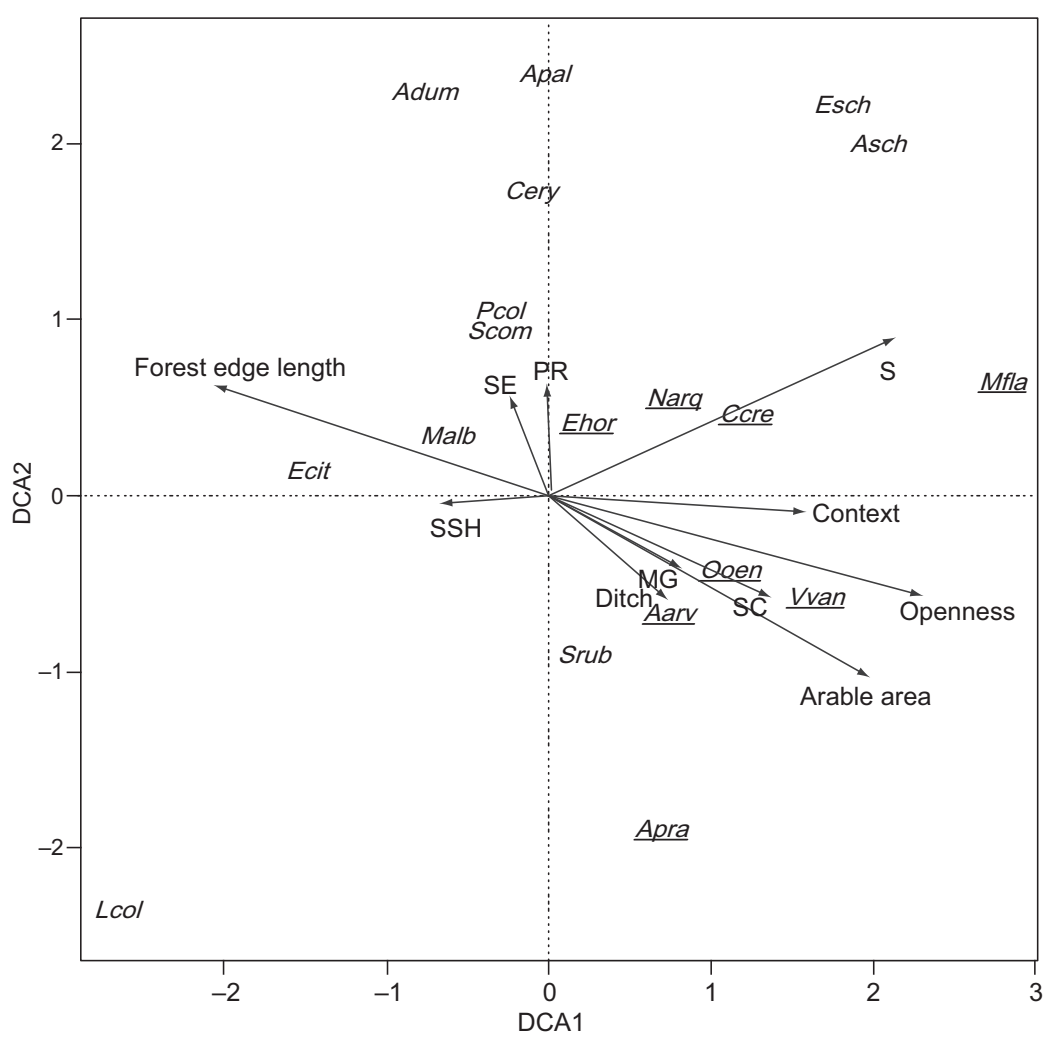

Fig. 2. The DCA ordination plot of species data, with significantly $(p<0.05)$ correlating variables fitted as vectors and shown by arrows. SE = settlement, $\mathrm{PR}=$ patch richness, $S=$ number of species, Context $=$ the area of agricultural land in the surrounding eight cells, $\mathrm{SC}=$ spring cereals, $\mathrm{MG}$ $=$ managed grasslands, $\mathrm{SSH}=$ small-scale habitat elements; for details on habitats, see Table 1 and text. Species occupying open, arable habitats are underlined; species occupying bush and edge habitats are not underlined. For species abbreviations, see Appendix 1. tats, and the axis reflects a gradient from large, open arable fields to smaller fragmented patches of farmland with lots of forest edge. The second axis was related to patch richness and settlements (including farmyards). Many of the edgeand bush-habitat species were ordered along the second axis, but not the first. Figure 2 shows the obvious intercorrelation that exists between (i) arable area, (ii) spring cereal, and (iii) managed grassland fields. Species richness was associated with samples where curlews, corncrakes (both SPEC species) and yellow wagtails were present. The following variables did not correlate significantly with the ordination: set-asides, root crops, roads, and the Shannon-Wiener species diversity.
RDA including all the variables explained $26.7 \%$ of the total inertia (variance), i.e. 0.0972 out of 0.3636 . The first four axes were statistically significant, and their eigenvalues were $0.059,0.0105,0.0081$, and 0.0073 , respectively, making up $87.3 \%$ of the combined eigenvalues of all the constrained axes. The first two axes were clearly the most important, accounting for $71.5 \%$ of the combined eigenvalues of all the constrained axes. All the explanatory variables were significant and are presented with the species in the biplot (Fig. 3a), along the first and second axis. Variation partitioning by partial RDAs showed the eleven environmental variables to be more significant and to explain more

Table 2. Detrended correspondence analysis of the species composition of all 19 species for the 368 grid cells.

\begin{tabular}{lccccc}
\hline & Axis 1 & Axis 2 & Axis 3 & Axis 4 $\begin{array}{c}\text { Sum of all } \\
\text { eigenvalues }\end{array}$ \\
\hline Eigenvalues & 0.288 & 0.174 & 0.131 & 0.116 & 0.709 \\
Axis lengths & 2.909 & 2.385 & 2.217 & 2.369 & 40.8 \\
Cumulative \% of total inertia explained & 16.6 & 26.6 & 34.2 & 40.8 \\
\hline
\end{tabular}



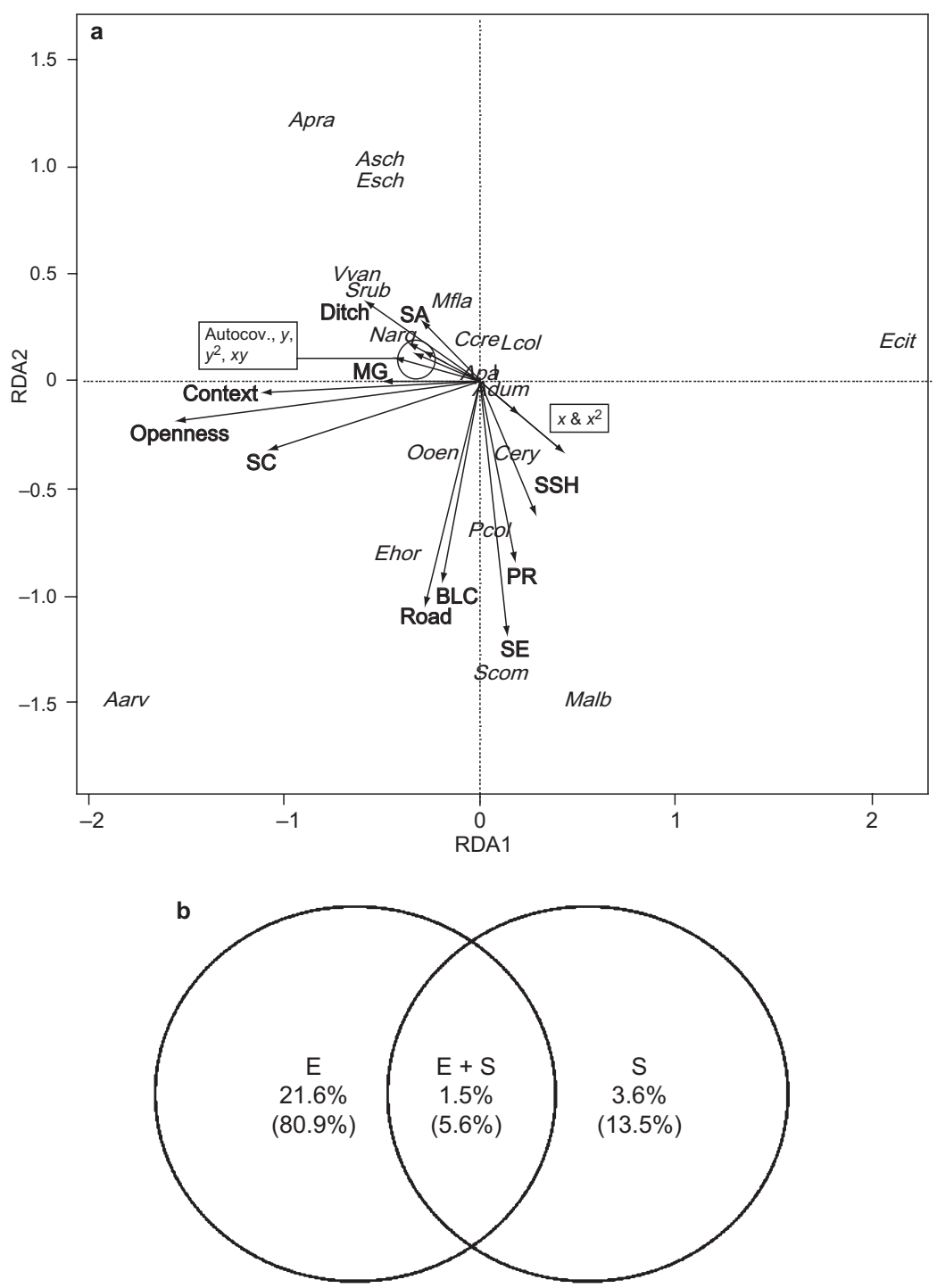

U $73.3 \%$

Fig. 3. - a: A biplot of species and explanatory environmental and spatial (in terms of geographical coordinates, and the total density as autocovariate; see boxes) variables for the first and second axes of RDA on the covariance matrix of the Hellinger distance-transformed species density data for the 368 grid cells. For clarity, the species are represented without arrows starting from the origin. $\mathrm{SA}=$ set-asides, $\mathrm{SSH}=$ small-scale habitat elements, PR = patch richness, $\mathrm{SE}=$ settlement, $\mathrm{BLC}=$ broad-leaved crops, $\mathrm{SC}=$ spring cereals, $\mathrm{MG}=$ managed grasslands . For details on habitats, see Table 1 and the text. For descriptions of spatial variables, see section 'Ordinations' in Methods. For species abbreviations, see Appendix 1. - b: Result of variation partitioning based on partial RDAs on the Hellinger-transformed species density data. The percentages show the proportions of total variation explained by each subset; the proportions accounted for by the explained variation are given in parentheses. Subsets: $\mathrm{E}$ $=$ pure environmental (the 11 environmental variables); $\mathrm{S}=$ pure spatial (the 6 spatial variables); $\mathrm{E}+\mathrm{S}=$ mixed environmental-spatial; $\mathrm{U}=$ unexplained.

of the variation than the six spatial variables, or the 'spatially structured environmental' fraction (Fig. 3b). As in DCA, the first RDA axis represented a gradient from large, open arable fields to smaller fragmented patches of farmland with lots of forest edge. The dominating cultivation type, spring cereals, had some association with the skylark, but with no other species. On the 
other hand, the curlew, lapwing, meadow pipit and yellow wagtail, which are also species of open arable habitats, were associated with open ditches and set-asides, and this was also the case with the whinchat. Thus we can say that these habitats increased the densities of these particular species. The sedge warbler and the reed bunting occurred predominantly in the largest sub-area (Fig. 1b) along wide open ditches (most of which were lined with bushes), which explains why these two species are grouped and located separately from the other edge and bush species. The second RDA axis represents a gradient that relates to non-cropped habitat heterogeneity, as shown by the variables 'patch richness', 'number of small-scale habitat elements', 'settlements' (including farmyards that are often sources of heterogeneity, with trees, etc.) and 'roads (including road banks)' (Fig. 3a). The area of broad-leaved crops also increased along the second axis. Several species of edge and bush habitats were associated with the second axis, as were the ortolan bunting and the wheatear.

Table 3 summarises the locations of the species along the first and second axis, and provides generalised interpretations of the effects on species brought about first of all by open arable habitat (axis 1), and secondly by habitat heterogeneity (axis 2). With the species selection, environmental variables, and ordination method used, eight species responded positively to the presence of open arable fields, ten rather neutrally, and one negatively. Seven species responded positively to heterogeneity, six

Table 3. Approximate locations of the species along the first ('open arable') and second ('habitat heterogeneity') RDA axes (Ax. 1 \& Ax. 2), with suggestive interpretations of the effects of these generalised habitat characteristics on species density. Minus and plus signs refer to the values of the axis.

\begin{tabular}{|c|c|c|c|}
\hline Species & Ax. 1 & Ax. 2 & Interpretation of the effects on species density \\
\hline Skylark (Aarv) & -- & -- & $\begin{array}{l}\text { Open arable: strong positive effect } \\
\text { Habitat heterogeneity: strong positive effect }\end{array}$ \\
\hline Meadow pipit (Apra) & - & ++ & Open arable: positive effect \\
\hline Sedge warbler (Asch) & - & ++ & Habitat heterogeneity: strong negative effect \\
\hline Reed bunting (Esch) & - & ++ & \\
\hline Lapwing (Vvan) & - & + & Open arable: positive effect \\
\hline Whinchat (Srub) & - & + & Habitat heterogeneity: negative effect \\
\hline Yellow wagtail (Mfla) & 0 & + & $\begin{array}{l}\text { Open arable: no effect } \\
\text { Habitat heterogeneity: negative effect }\end{array}$ \\
\hline Curlew (Narq) & $0(-)$ & 0 & $\begin{array}{l}\text { Open arable: possibly positive effect } \\
\text { Habitat heterogeneity: no effect }\end{array}$ \\
\hline Ortolan bunting (Ehor) & $0(-)$ & - & $\begin{array}{l}\text { Open arable: possibly positive effect } \\
\text { Habitat heterogeneity: positive effect }\end{array}$ \\
\hline Wheatear (Ooen) & 0 & - & Open arable: no effect \\
\hline Scarlet rosefinch (Cery) & 0 & - & Habitat heterogeneity: positive effect \\
\hline Pheasant $(P \mathrm{col})$ & 0 & - & \\
\hline Whitethroat (Scom) & 0 & -- & Open arable: no effect \\
\hline White wagtail (Malb) & 0 & -- & Habitat heterogeneity: strong positive effect \\
\hline Yelllowhammer (Ecit) & ++ & 0 & $\begin{array}{l}\text { Open arable: strong negative effect } \\
\text { Habitat heterogeneity: no effect }\end{array}$ \\
\hline Blyth's reed warbler (Adum) & 0 & 0 & Open arable: no effect \\
\hline Marsh warbler (Aris) & 0 & 0 & Habitat heterogeneity: no effect \\
\hline Corncrake (Ccre) & 0 & 0 & \\
\hline Red-backed shrike (Lcol) & 0 & 0 & \\
\hline
\end{tabular}


species responded negatively, and six species behaved neutrally.

\section{Spatial lag regressions on density and species richness}

Results of the spatial lag model for overall bird density $\left(D_{\text {total }}\right)$ and species richness $\left(S_{\text {total }}\right)$, and for the density and species richness of the two species groups separately $\left(D_{\text {open }}\right.$ and $S_{\text {open }}, D_{\text {edge }}$ and $S_{\text {edge }}$ respectively) are summarized in Table 4 . The positive spatial autocorrelation, as shown by the autoregressive component $(\varrho)$ and the likelihood ratio (LR) test value, was highly significant for all the density models and for $S_{\text {total }}$. As indicated by Moran's I values, spatial lag model specification overcame the problem of residual spatial autocorrelation, indicating that in methodological terms, autoregressive modelling was appropriate. Pseudo- $R^{2}$ values varied between 0.337 and 0.384 in the density models, and between 0.297 and 0.543 in the species richness models.

\section{Discussion}

\section{Environmental associations of birds}

Habitat homogenisation of cultivated areas, resulting from farm-level specialisation either in cereals or livestock keeping, has been a European-wide phenomenon during recent decades of agricultural intensification (Tucker \& Dixon 1997, Robinson \& Sutherland 2002, Benton et al. 2003). Our results demonstrate the importance of both non-cropped and cultivated habitat heterogeneity for bird assemblages living in intensively managed boreal farmland landscapes. True field species (i.e. species of open arable habitats) need openness in farmland, but, as shown by our results, benefit from the presence of grasslands, set-asides, and open ditches. Our results support findings from other studies (Berg 1994, Berg \& Pärt 1994, Piha et al. 2003, 2007a, Heikkinen et al. 2004, Virkkala et al. 2004, Wretenberg et al. 2007) indicating that grasslands and set-asides are among the most important factors determining the abundance and diversity of farmland birds in boreal agricultural landscapes. Set-asides have also been shown to be favoured by farmland birds in other parts of Europe (Chamberlain et al. 1999, Henderson et al. 2000, review by Van Buskirk \& Willi 2004, Bracken \& Bolger 2006).

In our study, the clearly dominating cultivation type, spring-sown cereals, had no significant effect on total density, or on the density of true field species, as shown by regression models; nor were true field species generally associated with that habitat in direct ordination. Nevertheless, while not promoting density, spring cereals along with other cultivation types had a positive effect on the total species richness, and on the species richness of true field species. This again indicates that diverse cultivation mosaics are important for species diversity. With regard to individual species, the most abundant species, the skylark, was associated with openness and spring cereals, but also with habitat heterogeneity. The area of spring cereals naturally strongly correlates with the area of arable land, and thus reflects the size of the patches of farmland, this latter feature being (according to Piha et al. 2003) one of the main factors explaining skylark densities in boreal field-forest mosaics. Furthermore, in our indirect ordination analysis, spring cereals (together with arable area and openness) correlated with the species optima of three true field species, the skylark, the wheatear, and the lapwing. By contrast, in the case of edge/bush species, the two most intensively managed cultivation types (spring cereals and root crops; Pitkänen \& Tiainen 2001) led to a decrease in the density. This may be connected to the intensive use of pesticides on these crops, which affects birds adversely via decreased availability of food supplies (Wilson et al. 1999, Atkinson et al. 2005).

Our results show that open ditches deserve special attention when one is considering heterogeneity of farmland habitats. Open ditches, which in our data include also ditch margins/ banks, had a positive effect both on total density and on species richness, and on the density and species richness of the two ecological groups studied. Among individual species, the whinchat and the lapwing were associated with open ditches, as shown by the direct ordination, and the skylark also correlated with this habitat in the indirect ordination. The meadow pipit was also 


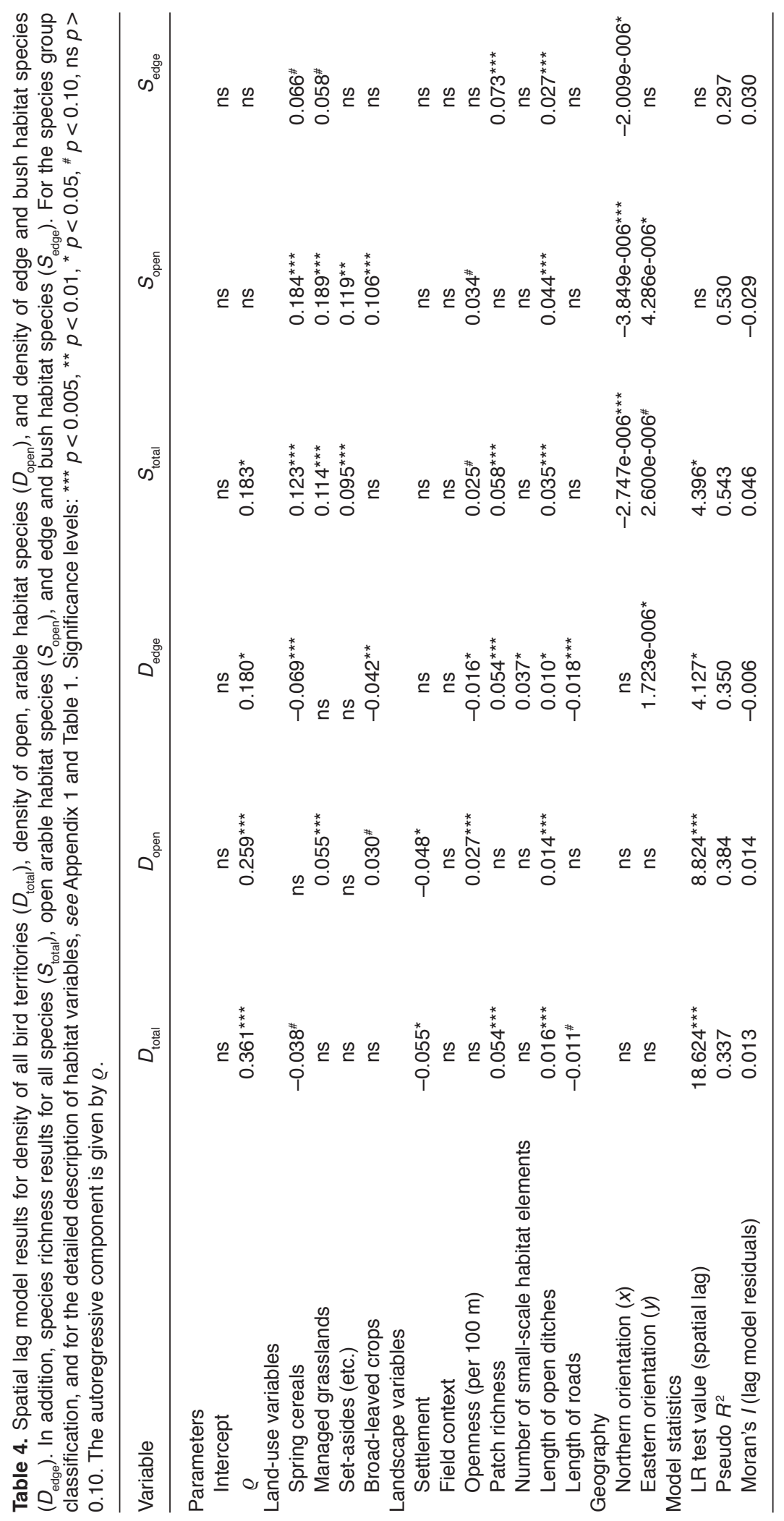


associated with open ditches, but more markedly with set-asides. In terms of both abundance and quality, field margins have been shown to be important for farmland birds, in that they provide foraging and breeding habitats (see Parish et al. 1995, Marshall \& Moonen 2002, Perkins et al. 2002, Vickery et al. 2002).

The edge and bush species benefited from overall habitat diversity (i.e. patch richness), open ditches, and small-scale habitat elements (i.e. bush and forest patches/islets $\leq 2 \mathrm{ha}$; ditches growing bushes and trees; road and field verges; wood avenues; and barns with their surroundings), emphasising the importance of non-cropped habitat diversity. Fuller et al. (2004) also emphasise the importance of non-cropped habitats for farmland birds as nesting, foraging or roosting places, and are of the opinion that the improvement of habitat diversity through provision of even modest quantities of these habitats is beneficial for farmland birds. The white wagtail, whitethroat, scarlet rosefinch, and pheasant were the edge/bush species most markedly related to non-cropped habitat heterogeneity. The ortolan bunting was positively affected by the same habitat features as the edge/bush species. This is reasonable, since although generally being a species of open landscapes, the ortolan bunting needs small-scale habitat features. These provide songposts that are important for the breeding groups of the species, and they also function as nesting and foraging places (Vepsäläinen et al. 2005b, 2007).

The area of scattered rural settlement (including farm-yards and gardens) had negative effects on the total density and on the density of the true field species. This is probably due to the selection of species for this study, bearing in mind that species of farmsteads and farmyards were not included. However, as shown by ordinations, the area of settlement had a positive effect on some individual species, namely the white wagtail, whitethroat, pheasant, and scarlet rosefinch, and to some extent also the wheatear and ortolan bunting. Farmyards, and other types of rural settlement surroundings, often contain rather diverse habitats within their area, such as bushes, trees, and garden vegetation (cf. Fuller et al. 2004). Furthermore, farmyards with livestock most probably also provide more invertebrate food than those without livestock.

\section{Spatial aspects}

Our results suggest some kind of positive effect on bird abundance and species richness deriving from a southern and eastern spatial orientation. This probably does not reflect any true geographical trend in our study area, but rather the fact that the largest area, Pukkila, is located in the eastern part of the entire study area, and also that there is more field area censused in the southern half of the study area than in the northern half. Spatiality did not play as significant a role on individual species as environmental factors. This was demonstrated by partial ordinations revealing that the spatial fraction explained far less of the total variation than did the environmental fraction. In the spatial lag regression models, however, the positive spatial autocorrelation was a significant factor explaining densities and total species richness. The observed positive autocorrelation may be caused by the spatial patterning of habitats or other environmental factors, or by population or community dynamic processes, for example by sociality causing spatial patterning, or by some other species-related factors (Legendre 1993). In this case, when the positive autocorrelation was observed at the level of species assemblages, we believe that more likely the spatial patterning of habitat factors is behind the observed autocorrelations, rather than that there would be sociality causing spatial cohesion in bird assemblages or communities.

\section{The Finnish AES, its measures, and their possible impacts on birds}

Appendix 2 lists those measures of the Finnish AES (for the subsidy period 2000-2006) which in expert evaluation were assessed as having potential positive effects on biodiversity (Kuussaari et al. 2004b, 2008), and thus also on farmland birds. Generally speaking, the measures of the Finnish AES included an emphasis on biodiversity issues. They were based on good intentions, but in practice most of the measures with potentially high bird diversity effects were far too infrequently applied and covered extremely small areas of the Finnish agricultural land (Appendix 2). A measure that is targeted at only a small 
fraction of the total arable area of Finland can be expected to have extremely local effects.

The AES resulted in the formation of margins along main ditches, and of border strips along larger water systems. The measure was applied to $94 \%$ of Finnish farmland (Kuussaari et al. 2004b, 2008). In fact, this is the obligatory basic measure that has probably been most beneficial to farmland birds, although the area covered by the margins is not large (Piha 2007).

Another basic measure that could potentially benefit farmland birds is the maintenance of biodiversity. This aspect would include actions such as the management of field-forest border zones, and the maintenance and management of tree and bush growing islets, with tree avenues and rock piles. In practice, however, farmers have often had difficulties in identifying biodiversity targets (which are often small-scale in nature) on their farms, and thus this measure has not been applied as widely as one would hope (Tiainen et al. 2004). There is an obvious need for more farm-level education and counselling on biodiversity aspects.

Of the voluntary special measures, organic farming may have a potential to benefit biodiversity, since (according to EC Reg. 2092/91) it aims to reduce the impact of agriculture on the environment by operating without pesticides or artificial fertilisers, and usually has more diverse crop rotation. Organic farming has been shown to benefit several taxa (Hole et al. 2005). However, recent studies in boreal agroecosystems have not found significant effects on birds, since the effects of organic farming may be overpowered by the effects of landscape structure or crop species (Belfrage et al. 2005, Bengtsson et al. 2005, Piha et al. 2007b).

\section{Proposals to improve the measures included in future AESs}

On the basis of our results, we suggest that the density and the species richness of boreal farmland avifauna will be positively affected by the presence and amount of: (i) open ditches delineating small fields (since small field size increases ditch density), (ii) diverse crop rotation that would create heterogeneous cultivation mosaics, with set-asides and grasslands, and (iii) non-cropped habitat heterogeneity.

Consequently, in order to maintain or increase the habitat features mentioned above, the following measures should be included within future AESs in Finland:

1. Maintenance of open ditches instead of subsurface drainage operations; ditch losses to be compensated by having strips of grass and bush groups in larger fields.

2. Promotion of diverse crop rotation, including grasslands and fallowing (with both rotational and long-term set-asides).

3. Maintenance of tree and bush vegetation in islets and along tree and bush-lined ditches.

4. The widening and overall management of field banks, border strips, and border zones.

5. More biodiversity education to be given to farmers, to help them identify important conservation/management targets at the farm level, and to direct actions adequately.

The fourth and the fifth items of the above list have already been included in the Finnish AES during the first or second programme periods; however, it would be important to include them also in the future, and to apply them to larger areas than previously.

The objective of maintaining open ditches is in conflict with the sub-surface drainage agenda of the 'Horizontal Rural Development Programme', which aims, by 2020, to apply subsurface drainage to the $50 \%$ of Finnish arable area still drained by open ditches (Anon. 2004). The agenda does not assess the biodiversity effects of sub-surface drainage. The agenda is justified mainly by the efficiency of drainage, the improvement of soil structure, the rationalisation of field work, a decrease in erosion and in phosphorous leaching into water systems, and a decrease in greenhouse gas emissions (Anon. 2004). In 2000, 58\% of Finnish fields were drained by sub-surface drainage, $(69 \%$ in southern Finland), while the percentage of fields still drained by open ditches was $27 \%$ (15\% in the south; Anon. 2004). The expansion of subsurface drainage should be carefully considered from the biodiversity point of view in future assessments of the national AES. 
As regards the diversity of cultivations, such diversity is highest in livestock farms which conduct crop rotation with food plants, fodder plants and pasture (Piha 2007). For several decades, livestock farms have been decreasing in overall number, and in the proportion relative to all farms in Finland. The decrease has amounted to $25 \%$ over the last ten years, and it will continue in the near future (Lehtonen \& Pyykkönen 2005). In practice, the decrease in animal farming will cause a further decline in grassland habitats through a decrease in the need for fodder production. The most pronounced decrease in animal farming will be in northern and eastern Finland (Lehtonen \& Pyykkönen 2005), but in southern Finland too, the ongoing trend will most probably cause many livestock farms to switch to cereal and/or root crop cultivation. Thus, grassland habitats will be regionally concentrated, while spring cereal cultivation will dominate even more than before. Given that grassland habitats are important for farmland birds as a fundamental part of diverse cultivation mosaics, the recent trend should definitely be taken into account when consideration is given to AES measures that could maintain or even increase farmland biodiversity.

With regard to measures in the Finnish AES for the ongoing subsidy period (2007-2013), there have in fact been a few changes regarding biodiversity-related measures (Anon. 2007). 'Vegetation covered set-aside' (with a minimum duration of two years) is a new measure included in the basic measures. Under the additional measures we also find 'diversification of cultivation', which means that each year a maximum of $40 \%$ of a farm's cultivated area may be cultivated for any one particular crop species, and that one particular crop species may be cultivated in the same field parcel for a maximum of two consecutive years (or for ley/silage three years). The effects of these two measures on farmland biodiversity remain to be seen.

\section{Acknowledgements}

This paper greatly benefited from comments by Johan Ekroos, Irina Herzon, Jaakko Järvinen, Timo Pakkala and Kari Vepsäläinen. Special thanks to Mike Palmer for his help and comments on ordination methods. Donald Adamson kindly revised the English. This study belonged to the study of biodiversity impacts of the Finnish agri-environmental scheme, financed by the Ministry of Agricultural and Forestry, and to a project financed by the Maj and Tor Nessling Foundation. VV was also supported by Jenny and Antti Wihuri Foundation and the Finnish Cultural Foundation.

\section{References}

Anon. 2001: The yearbook of farm statistics 2000. - Official Statistics of Finland, Information Centre of the Ministry of Agriculture and Forestry, Helsinki.

Anon. 2004: Mid-term evaluation of the Horizontal Rural Development Programme. - Publ. Ministry of Agriculture and Forestry (MMM) 1/2004, Helsinki, Finland. [In Finnish with English summary].

Anon. 2005: Statistical yearbook of forestry 2005. - Finnish Forest Research Institute.

Anon. 2006: The yearbook of farm statistics 2005. - Official Statistics of Finland, Information Centre of the Ministry of Agriculture and Forestry, Helsinki.

Anon. 2007: Manner-Suomen maaseudun kehittämisohjelma 2007-2013. CCI 2007 FI 06 RPO 001. - Ministry of Agriculture and Forestry (MMM).

Anselin, L. 2002: Under the hood - Issues in the specification and interpretation of spatial regression models. Agricultural Economics 27: 247-267.

Anselin, L. \& Bera, A. 1998: Spatial dependence in linear regression models with an introduction to spatial econometrics. - In: Ullah, A. \& Giles, D. E. (eds.), Handbook of applied economic statistics: 237-289. Marcel Dekker, New York.

Anselin, L., Syabri, I. \& Kho Y. 2006: GeoDa: an introduction to spatial data analysis. - Geogr. Anal. 38: 5-22.

Atkinson, P. W., Fuller, R. J., Vickery, J. A., Conway, G. J., Tallowin, J. R. B., Smith, R. E. N., Haysom, K. A., Ings, T. C., Asteraki, E. J. \& Brown, V. K. 2005: Influence of agricultural management, sward structure and food resources on grassland field use by birds in lowland England. - J. Appl. Ecol. 42: 932-942.

Belfrage, K., Björklund, J. \& Salomonsson, L. 2005: The effects of farm size and organic farming on diversity of birds, pollinators, and plants in a Swedish landscape. Ambio 34: 582-588.

Bengtsson, J., Ahnström, J. \& Weibull, A.-C. 2005: The effects of organic agriculture on biodiversity and abundance: a meta-analysis. - J. Appl. Ecol. 42: 261-269.

Benton, T. G., Vickery, J. A. \& Wilson, J. D. 2003: Farmland biodiversity: is habitat heterogeneity the key? - Trends in Ecology and Evolution 18: 182-188.

Berg, A. 1994: Maintenance of populations and causes of population changes of curlews Numenius arquata breeding on farmland. - Biol. Cons. 67: 233-238.

Berg, Å. \& Pärt, T. 1994: Abundance of breeding farmland birds on arable and set-aside fields at forest edges. Ecography 17: 147-152.

Bibby, C. J., Burgess, N. D. \& Hill, D. A. 2000: Bird census techniques, 2nd ed. - Academic Press, London.

BirdLife International 2004: Birds in Europe: population 
estimates, trends and conservation status. - BirdLife Conservation Series no. 12, Cambridge, UK.

Böhning-Gaese, K. 1997: Determinants of avian species richness at different spatial scales. - J. Biogeography 24: 49-60.

Borcard, D., Legendre, P. \& Drapeau, P. 1992: Partialling out the spatial component of ecological variation. - Ecology 73: 1045-1055.

Bracken, F. \& Bolger, T. 2006: Effects of set-aside management on birds breeding in lowland Ireland. - Agriculture, Ecosystems and Environment 117: 178-184.

Chamberlain, D. E., Wilson, A. M., Browne, S. J. \& Vickery, J. A. 1999: Effects of habitat type and management on the abundance of skylarks in the breeding season. $-J$. Appl. Ecol. 36: 856-870.

Chamberlain, D. E., Fuller, R. J., Bunce, R. G. H., Duckworth, J. C. \& Shrubb, M. 2000: Changes in abundance of farmland birds in relation to the timing of agricultural intensification in England and Wales. - J. Appl. Ecol. 37: 771-788.

Donald, P. F., Green, R. E. \& Heath, M. F. 2001: Agricultural intensification and the collapse of Europe's farmland bird populations. - Proc. Royal Soc. London B 268: 25-29.

Donald, P. F., Pisano, G., Rayment, M. D. \& Pain, D. J. 2002: The Common Agricultural Policy, EU enlargement and the conservation of Europe's farmland bird. - Agriculture, Ecosystems and Environment 89: 167-182.

Donald, P. F., Sanderson, F. J., Burfield, I. J. \& van Bommel, F. P. J. 2006: Further evidence of continent-wide impacts of agricultural intensification on European farmland birds, 1990-2000. - Agriculture, Ecosystems and Environment 116: 189-196.

Ferrier, S. \& Guisan, A. 2006: Spatial modelling of biodiversity at community level. - J. Appl. Ecol. 43: 393-404.

Fuller, R. J., Gregory, R. D., Gibbons, D. W., Marchant, J. H., Wilson, J. D., Baillie, S. R. \& Carter, N. 1995: Population declines and range contractions among lowland farmland birds in Britain. - Cons. Biol. 9: 1425-1441.

Fuller, R. J., Hinsley, S. A. \& Swetnam, R. D. 2004: The relevance of non-farmland habitats, uncropped areas and habitat diversity to the conservation of farmland birds. - Ibis 146 (Suppl. 2): 22-31.

Gimona, A. \& Brewer, M. J. 2006: Local environmental effects and spatial effects in macroecological studies using mapped abundance classes: the case of the rook Corvus frugilegus in Scotland. - J. Appl. Ecol. 75: 1140-1146.

Green, R. E., Cornell, S. J., Scharlemann, J. P. W. \& Balmford, A. 2005: Farming and the fate of wild nature. Science 307: 550-555.

Hanski, I. \& Tiainen J. 1988: Populations and communities in changing agro-ecosystems in Finland. - Ecol. Bull. 39: $159-168$.

Härmä, P., Teiniranta, R., Törmä, M., Repo, R., Järvenpää, E. \& Kallio, M. 2004: Production of CORINE2000 landcover using calibrated LANDSAT 7 ETM satellite image mosaics and digital maps in Finland. - In: IGRASS 2004, IEEE International Geoscience and Remote sensing Symposium Proceedings, 20-24 September 2004,
Ancorage, Alaska, vol. 4: 2703-2706. IEEE.

Heikkinen, R. K., Luoto, M., Virkkala, R. \& Rainio, K. 2004: Effects of habitat cover, landscape structure and spatial variables on the abundance of birds in an agriculturalforest mosaic. - J. Appl. Ecol. 41: 824-835.

Henderson, I. G., Cooper, J., Fuller, R. J. \& Vickery, J. 2000: The relative abundance of birds on set-aside and neighbouring fields in summer. - J. Appl. Ecol. 37: 335-347.

Herzon, I. \& O'Hara, R. B. 2007: Effects of landscape complexity on farmland birds in the Baltic States. - Agriculture, Ecosystems and Environment 118: 297-306.

Hill, M. O. \& Gauch, H. G. Jr. 1980: Detrended correspondence analysis: an improved ordination technique. Vegetatio 42: 47-58.

Hole, D. G., Perkins, A. J., Wilson, J. D., Alexander, I. H., Grice, P. V. \& Evans, A. D. 2005: Does organic farming benefit biodiversity? - Biol. Cons. 122: 113-130.

Kenkel, N. C. 2006: On selecting appropriate multivariate analysis. - Can. J. Plant Sci. 86: 663-676.

Kleijn, D., Berendse, F., Smit, R. \& Glissen, N. 2001: Agrienvironment schemes do not effectively protect biodiversity in Dutch agricultural landscapes. - Nature 413: 723-725.

Kleijn, D. \& Sutherland, W. J. 2003: How effective are agri-environment schemes in conserving and promoting biodiversity? - J. Appl. Ecol. 40: 947-969.

Kujawa, K. 2002: Population density and species composition changes for breeding bird species in farmland woodlots in western Poland between 1964 and 1994. Agriculture, Ecosystems and Environment 91: 261-271.

Kuussaari, M., Tiainen, J., Helenius, J., Hietala-Koivu, R. \& Heliölä, J. (eds.) 2004a: Significance of the Finnish agri-environment support scheme for biodiversity and landscape: Results of the MYTVAS project 2000-2003. - Suomen ympäristö 709: 1-212. [In Finnish with English summary].

Kuussaari, M., Rekolainen, S., Tattari, S., Heliölä, J. \& Luoto, M. 2004b: Maatalouden ympäristötuen merkitys luonnon monimuotoisuudelle. - In: Tiainen, J., Kuussaari, M., Laurila, I. P. \& Toivonen, T. (eds.), Elämää pellossa, Suomen maatalousympäristön monimuotoisuus: 258-276. Edita Publishing Oy, Helsinki, Finland.

Kuussaari, M., Heliölä, J., Tiainen, J. \& Helenius, J. (eds.) 2008: Significance of the Finnish agri-environmental support scheme for biodiversity and landscape: Final report 2000-2006. - Suomen ympäristö 4/2008: 1-208. [In Finnish with English abstract].

Laiolo, P. 2005: Spatial and seasonal patterns of bird communities in Italian agroecosystems. - Cons. Biol. 19: 1547-1556.

Legendre, P. 1993: Spatial autocorrelation: trouble or new paradigm? - Ecology 74: 1659-1673.

Legendre P. \& Legendre L. 1998: Numerical ecology, 2nd English ed. - Elsevier, Amsterdam.

Legendre, P. \& Gallagher, E. 2001: Ecologically meaningful transformations for ordination of species data. - Oecologia 129: 271-280.

Lehtonen, H. \& Pyykkönen, P. 2005: Structural change in Finnish agriculture up to 2013. - MTT:n selvityksiä 100. [In Finnish with English summary]. 
Lichstein, J. W., Simons, T. R., Shriner, S. A. \& Franzreb, K. E. 2002: Spatial autocorrelation and autoregressive models in ecology. - Ecol. Monogr. 72: 445-463.

Luoto, M., Virkkala, R., Heikkinen, R. K. \& Rainio, K. 2004: Predicting bird species richness using remote sensing in boreal agricultural-forest mosaics. - Ecol. Appl. 14: 1946-1962.

Marshall, E. J. R. \& Moonen, A. C. 2002: Field margins in northern Europe: their functions and interactions with agriculture. - Agriculture, Ecosystems and Environment 89: 5-21.

McGarigal, K., Cushman, S. A., Neel, M. C. \& Ene, E. 2002: FRAGSTATS: Spatial pattern analysis program for categorical maps. - Computer software program produced by the authors at the University of Massachusetts, Amherst.

Newton, I. 2004: The recent declines of farmland bird populations in Britain: an appraisal of causal factors and conservation actions. - Ibis 146: 579-600.

Oksanen, J. 2006: Multivariate analysis of ecological communities. - In: R: vegan tutorial, available at http:// cc.oulu.fi/ jarioksa/opetus/metodi/vegantutor.pdf.

Oksanen, J., Kindt, R., Legendre, P. \& O'Hara, R. B. 2007: Vegan: community ecology package version 1.8-5. Available at http://cran.r-project.org.

Parish, T., Lakhani, K. H. \& Sparks, T. H. 1995: Modelling the relationship between bird population variables and hedgerow, and other field margin attributes. II. Abundance of individual species and of groups of similar species. - J. Appl. Ecol. 32: 362-371.

Pärt, T. \& Söderström, B. 1999: The effects of management regimes and location in landscape on the conservation of farmland birds breeding in semi-natural grasslands. Biol. Cons. 90: 113-123.

Perkins, A. J., Whittingham, M. J., Morris, A. J. \& Bradbury, R. B. 2002: Use of fields by foraging yellowhammers Emberiza citrinella. - Agriculture, Ecosystems and Environment 93: 413-420.

Piha, M. 2007: Spatial and temporal determinants of Finnish farmland bird populations. - Ph.D. thesis, University of Helsinki.

Piha, M., Pakkala, T. \& Tiainen, J. 2003: Habitat preferences of the skylark Alauda arvensis in southern Finland. Ornis Fennica 80: 97-110.

Piha, M., Lindén, A., Pakkala, T. \& Tiainen, J. 2007a: Linking weather and habitat to population dynamics of migratory farmland songbirds. - Ann. Zool. Fennici 44: 20-34.

Piha, M., Tiainen, J., Holopainen, J. \& Vepsäläinen, V. 2007b: Effects of land-use and landscape characteristics on avian diversity and abundance in a boreal agricultural landscape with organic and conventional farms. - Biol. Cons. 140: 50-61.

Pitkänen, M. \& Tiainen, J. (eds.) 2001: Biodiversity of agricultural landscapes in Finland. - BirdLife Finland Conservation Series no. 3. Yliopistopaino, Helsinki.

Rangel, T. F. L. V. B., Diniz-Filho, J. A. F. \& Bini, L. M. 2006: Towards an integrated computational tool for spatial analysis in macroecology and biogeography. Global Ecol. Biogeogr. 15: 321-327.
Rintala, J., Tiainen, J. \& Pakkala, T. 2003: Population trends of Finnish starling Sturnus vulgaris, 1952-1998, as inferred from annual ringing totals. - Ann. Zool. Fennici 40: 365-385.

Rintala, J. \& Tiainen, J. 2007: Indexing long-term regional bird population dynamics with nestling ringing data. Ann. Zool. Fennici 44: 115-140.

Robinson, R. A. \& Sutherland, W. J. 2002: Changes in arable farming and biodiversity in Great Britain. - J. Appl. Ecol. 39: 157-176.

Siriwardena, G. M., Baillie, S. R., Buckland, S. T., Fewster, R. M., Marchant, J. H. \& Wilson, J. D. 1998: Trends in the abundance of farmland birds: a quantitative comparison of smoothed common bird census indices. $-J$. Appl.Ecol. 35: 24-43.

Stoate, C., Boatman, N. D., Borralho, R. J., Rio Carvalho, C., de Snoo, G. R. \& Eden, P. 2001: Ecological impacts of arable intensification in Europe. - J. Env. Manage. 63: 337-365.

Tiainen, J., Pakkala, T., Piiroinen, J., Vickholm, M. \& Virolainen, E. 1985: Changes of the avifauna of farmland at Lammi, southern Finland during the past 50 years. - Lintumies 20: 30-42. [In Finnish with English summary].

Tiainen, J. \& Pakkala, T. 2000: Population changes and monitoring of farmland birds in Finland. - Linnutvuosikirja 1999: 98-105. [In Finnish with English summary].

Tiainen, J. \& Pakkala, T. 2001: Birds. - In: Pitkänen, M. \& Tiainen, J. (eds.), Biodiversity of agricultural landscapes in Finland: 33-50. BirdLife Finland Conservation Series no. 3, Yliopistopaino, Helsinki, Finland.

Tiainen, J., Holopainen, J., Seimola, T., Ekroos, J., Piha, M. \& Vepsäläinen, V. 2004: Maatalousympäristön pesimälinnuston seuranta. - Suomen ympäristö 709: 92-109.

Tilman, D., Fargione, J., Wolff, B., D'Antonio, C., Dobson, A., Howarth, R., Schindler, D., Schlesinger, W. H., Simberloff, D. \& Swackhamer, D. 2001: Forecasting agriculturally driven global environmental change. Science 292: 281-284.

Tognelli, M. F. \& Kelt, D. A. 2004: Analysis of determinants of mammalian species richness in South America using spatial autoregressive models. - Ecography 27: 427-436.

Tryjanowski, P. 1999: Effect of habitat diversity on breeding birds: comparison of farmland bird community in the region of Wielkopolska (W. Poland) with relevant data from other European studies. - Pol. J. Ecol. 47: 153-174.

Tucker, G. M. \& Dixon, J. 1997: Agricultural and grassland habitats. - In: Tucker, G. M., Evans \& M. I. (eds.), Habitats for birds in Europe: a conservation strategy for the wider environment: 267-325. BirdLife Conservation Series no. 6, Cambridge, U.K.

Väisänen, R. A., Lammi, E. \& Koskimies, P. 1998: Distribution, numbers and population trends of Finnish breeding birds. - Otava, Keuruu. [In Finnish with English summary].

Van Buskirk, J. \& Willi, Y. 2004: Enhancement of farmland biodiversity within set-aside land. - Cons. Biol. 18: 
987-994.

Vepsäläinen, V., Pakkala, T. \& Tiainen, J. 2005a: Population increase and aspects of colonization of the tree sparrow Passer montanus, and its relationships with the house sparrow Passer domesticus, in the agricultural landscapes of southern Finland. - Ornis Fennica 82: $117-128$

Vepsäläinen, V., Pakkala, T., Piha, M. \& Tiainen, J. 2005b: Population crash of the ortolan bunting Emberiza hortulana in agricultural landscapes of southern Finland. - Ann. Zool. Fennici 42: 91-107.

Vepsäläinen, V., Pakkala, T., Piha, M. \& Tiainen, J. 2007: The importance of breeding groups for territory occupancy in a declining population of a farmland passerine bird. - Ann. Zool. Fennici 44: 8-19.

Vickery, J. A., Carter, N. \& Fuller, R. J. 2002: The potential value of managed cereal field margins as foraging habitats for farmland birds in the UK. - Agriculture, Ecosystems and Environment 89: 41-52.
Virkkala, R., Luoto, M. \& Rainio, K. 2004: Effects of landscape composition on farmland and red-listed birds in boreal agricultural-forest mosaics. - Ecography 27: 273-284.

Whittingham, M. J., Krebs, J. R., Swetnam, R. D., Vickery, J. A., Wilson, J. D. \& Freckleton, R. P. 2007: Should conservation strategies consider spatial generality? Farmland birds show regional not national patterns of habitat association. - Ecology Letters 10: 25-35.

Wilson, J. D., Morris, A. J., Arroyo, B. E., Clark, S. C. \& Bradbury, R. B. 1999: A review of the abundance and diversity of invertebrate and plant foods of granivorous birds in northern Europe in relation to agricultural change. - Agriculture, Ecosystems and Environment 75: $13-30$.

Wretenberg, J., Lindström, Å., Svensson, S., Thierfelder, T. \& Pärt, T. 2006: Population trends in Sweden and England: similar trends but different patterns of agricultural intensification. - J.Appl. Ecol. 43: 1110-1120.

Appendix 1. Descriptive statistics of bird species. The density is calculated as number of territories per $\mathrm{km}^{2}$ of agricultural land (Table 1), for the entire study area. After the species Latin names in parenthesis abbreviations derived from the the Latin names are given. A boldface letter $\mathbf{A}$ or $\mathbf{E}$ indicates classification of the species as a species of predominantly open, arable habitats or as species of predominantly edge and bush habitats, respectively. Species with unfavourable conservation status in Europe are underlined, and SPEC category (1-3) is indicated by a superscript (BirdLife International 2004).

\begin{tabular}{|c|c|c|c|}
\hline Species & Territories $(n)$ & Density & $\begin{array}{c}\text { Number of cells } \\
\text { where present }\end{array}$ \\
\hline Pheasant Phasanius colchicus (Pcol) E & 107 & 1.6 & 82 \\
\hline Corncrake Crex crex (Ccre) $\mathbf{A}^{1}$ & 35 & 0.5 & 31 \\
\hline Lapwing Vanellus vanellus (Vvan) $\mathbf{A}^{2}$ & 192 & 2.9 & 96 \\
\hline Curlew Numenius arquata (Narq) $\mathbf{A}^{2}$ & 106 & 1.6 & 101 \\
\hline Skylark Alauda arvensis (Aarv) $\mathbf{A}^{3}$ & 2020 & 30.2 & 314 \\
\hline Meadow pipit Anthus pratensis (Apra) A & 444 & 6.6 & 173 \\
\hline Yellow wagtail Motacilla flava (Mfla) A & 48 & 0.7 & 22 \\
\hline White wagtail Motacilla alba (Malb) E & 500 & 7.5 & 282 \\
\hline Whinchat Saxicola rubetra (Srub) E & 375 & 5.6 & 197 \\
\hline Wheatear Oenanthe oenanthe (Ooen) $\mathbf{A}^{3}$ & 68 & 1.0 & 54 \\
\hline Grasshopper warbler Locustella naevia (Lnae) E & 7 & 0.1 & 7 \\
\hline Sedge warbler Acrocephalus schoenob. (Asch) E & 163 & 2.4 & 70 \\
\hline Blyth's reed warbler $A$. dumetorum (Adum) E & 20 & 0.3 & 16 \\
\hline Marsh warbler A. palustris (Apa) $\mathbf{E}$ & 27 & 0.4 & 22 \\
\hline Whitethroat Sylvia communis (Scom) E & 795 & 11.9 & 299 \\
\hline Red-backed shrike Lanius collurio (Lcol) $\mathbf{E}^{3}$ & 36 & 0.5 & 36 \\
\hline Scarlet rosefinch Carpodacus erythrinus (Cery) E & 136 & 2.0 & 89 \\
\hline Yellowhammer Emberiza citrinella (Ecit) $\mathbf{E}$ & 1045 & 15.6 & 324 \\
\hline Ortolan bunting Emberiza hortulana (Ehor) $\mathbf{A}^{2}$ & 222 & 3.3 & 121 \\
\hline Reed bunting Emberiza schoeniclus (Esch) E & 146 & 2.2 & 79 \\
\hline All species & 6492 & 97.1 & \\
\hline
\end{tabular}


Appendix 2. Finnish AES measures (the second subsidy period: 2000-2006) that are assessed to have biodiversity effects (mainly derived from Tiainen et al. 2004: 262; see also Anon. 2004), with speculations on their significance and relevance for birds. Statistics are from 2001-2002.

\begin{tabular}{|c|c|c|c|c|}
\hline Measure & $\begin{array}{l}\text { Number of } \\
\text { agreements }\end{array}$ & $\begin{array}{l}\text { Covered } \\
\text { area } \\
\left(\mathrm{km}^{2}\right)\end{array}$ & $\begin{array}{l}\text { Percentage } \\
\text { of total } \\
\text { agricult. } \\
\text { area }\end{array}$ & Probable significance for birds \\
\hline Basic & 68803 & 22083 & 98.23 & \\
\hline $\begin{array}{l}\text { Environmental planning and } \\
\text { farmers monitoring of cultivation }\end{array}$ & & & & $\begin{array}{l}\text { May have positive effect, since possibly } \\
\text { increases environmental consciousness } \\
\text { of farmers. }\end{array}$ \\
\hline $\begin{array}{l}\text { Formation of field banks (width } 1 \mathrm{~m} \text { ) } \\
\text { generally along main ditches, and } \\
\text { border strips (width } 3 \mathrm{~m} \text { ) along } \\
\text { water systems }\end{array}$ & & $\begin{array}{l}\text { ca. } 42 \\
\text { (length ca. } \\
13800 \text { km) }\end{array}$ & & $\begin{array}{l}\text { Increases non-cropped habitat } \\
\text { heterogeneity and amount, and thus } \\
\text { probably has positive effects. }\end{array}$ \\
\hline Maintenance of biodiversity* & & & & $\begin{array}{l}\text { Generally, positive effects. However, } \\
\text { farmers have had difficulties to identify } \\
\text { biodiversity targets and fulfil this } \\
\text { measure (Tiainen et al. 2004). }\end{array}$ \\
\hline \multicolumn{5}{|l|}{ Additional $^{\star \star}$} \\
\hline $\begin{array}{l}\text { Wintertime vegetation cover and } \\
\text { lightened tilling }\end{array}$ & 35114 & 8874 & 39.50 & $\begin{array}{l}\text { May provide food during migration } \\
\text { period, and also increase abundance of } \\
\text { soil invertebrates and thus food for } \\
\text { birds; however, increase in herbicide } \\
\text { use may have negative effects } \\
\text { (Cunningham et al. 2004). }\end{array}$ \\
\hline Farm-level biodiversity targets ${ }^{\star * *}$ & 352 & 80 & 0.36 & $\begin{array}{l}\text { Probably only some local positive } \\
\text { effects, since area covered is extremely } \\
\text { small. }\end{array}$ \\
\hline \multicolumn{5}{|l|}{ Special } \\
\hline $\begin{array}{l}\text { Formation and management of } \\
\text { border zones (wider than border } \\
\text { strips, mean approximately } 25 \mathrm{~m} \text { ) }\end{array}$ & 2097 & 54 & 0.24 & $\begin{array}{l}\text { Probably only some local positive } \\
\text { effects, since area covered is extremely } \\
\text { small. }\end{array}$ \\
\hline $\begin{array}{l}\text { Formation and management of } \\
\text { wetlands and sedimentation basins }\end{array}$ & 425 & 48 & 0.22 & $\begin{array}{l}\text { Wetland species of this study, the sedge } \\
\text { warbler and the reed bunting, probably } \\
\text { benefit. However, area covered is } \\
\text { extremely small. }\end{array}$ \\
\hline $\begin{array}{l}\text { Management of traditional } \\
\text { farmland habitat(s) }\end{array}$ & 2538 & 237 & 1.05 & $\begin{array}{l}\text { Conserves diversity of landscape, } \\
\text { effects on birds in the wider agricultural } \\
\text { context difficult to assess. }\end{array}$ \\
\hline $\begin{array}{l}\text { Improvement and management of } \\
\text { landscape }\end{array}$ & 1052 & 40 & 0.18 & $\begin{array}{l}\text { Conserves diversity of landscape, } \\
\text { species of open fields may benefit }\end{array}$ \\
\hline Improvement of biodiversity ${ }^{\star \star \star \star *}$ & 846 & 36 & 0.16 & $\begin{array}{l}\text { Probably positive effects, but area } \\
\text { covered is extremely small. }\end{array}$ \\
\hline Organic production & 4782 & 1497 & 6.66 & $\begin{array}{l}\text { Diverse crop rotation creates habitat } \\
\text { heterogeneity, and thus is beneficial for } \\
\text { birds. Also, prohibition of pesticide use } \\
\text { probably has positive effects via } \\
\text { increased availability of insect and seed } \\
\text { food. }\end{array}$ \\
\hline
\end{tabular}

* Includes management acts to maintain biodiversity targets on farm scale, for example: tree-and bush islets, field-forest border zones, big rock piles, and tree avenues. ${ }^{* *}$ Farmer may choose only one of the six additional measures. ${ }^{* *}$ Objectives: to increase farmer's knowledge on plant and animal species and their habitats on his/ her farm, on management of habitats. ${ }^{* \star \star \star}$ Objectives: to increase openness and diversity of landscape, to increase landscape characteristics, and to manage valuable agricultural landscapes ${ }^{* * \star *}$ Objectives: to promote diversity of plants and animals, ecosystems, and habitat types. 